
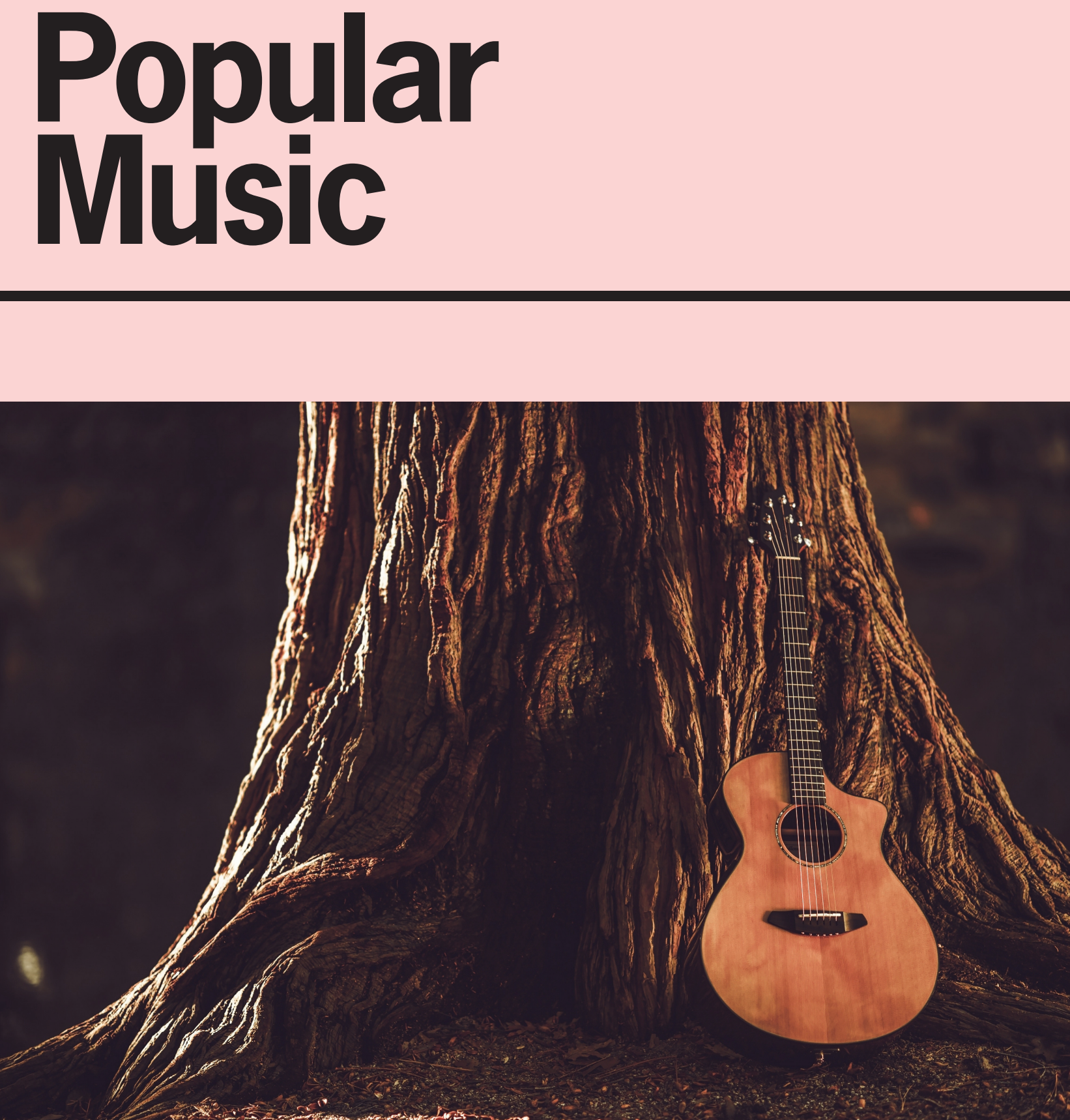

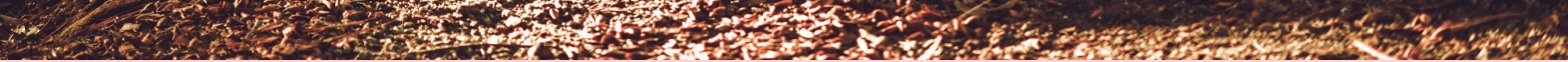


Editorial Group

MARTIN CLOONAN (Co-ordinating Editor)

NANETTE DE JONG

DAI GRIFFITHS (Book Revieww Editor)

SARAH HILL (Co-ordinating Editor)

\section{Founding Editors}

DAVID HORN

RICHARD MIDDLETON

\section{International Advisory Editors}

Christopher Ballantine (South Africa)

Nicole Biamonte (Canada)

Alf Björnberg (Sweden)

Barbara Bradby (Ireland)

Sara Cohen (UK)

Anne Danielsen (Norway)

Nicola Dibben (UK)

Franco Fabbri (Italy)

Murray Forman (USA)

Héctor Fouce (Spain)

Simon Frith (UK)

Juan Pablo González (Chile)

Lucy Green (UK)

Line Grenier (Canada)

Jill Halstead (Norway)

Stan Hawkins (Norway)

(c) Cambridge University Press 2019
BARBARA LEBRUN

ALLAN MOORE

KEITH NEGUS

JOHN STREET

Popular Music is an international multi-disciplinary journal covering all aspects of the subject - from the formation of social group identities through popular music, to the workings of the global music industry, to how particular pieces of music are put together. The journal includes all kinds of popular music, whether rap or rai, jazz or rock, from any historical era and any geographical location. Popular Music carries articles by scholars from a variety of disciplines and theoretical perspectives. Each issue contains substantial, authoritative and influential articles, topical pieces, and reviews of a wide range of books. Some issues are thematic. The editors also welcome polemical pieces for the 'Middle Eight' section of the journal. Contributors should consult the 'Notes' on the inside back cover.

Articles and any other material not related to reviews should be submitted online at cambridge.org/pmu. Any queries relating to submissions may be addressed to popularmusic@cambridge.org. Material for review should be sent to Dai Griffiths, email dmgriffiths@brookes.ac.uk.

Subscriptions Popular Music (ISSN 0261-1430) is published three times a year in January, May and October. Three parts form a volume. The subscription price (excluding VAT) of Volume 38 which includes print and electronic access to institutional subscribers is $£ 350$ (USA, Canada and Mexico \$597); print only for individuals is $£ 66$ (USA, Canada and Mexico \$98). Single parts cost $£ 134$ (USA, Canada and Mexico \$229). An online only price is available to institutional subscribers for $£ 301$ (USA, Canada and Mexico \$504). EU subscribers (outside the UK) who are not registered for VAT should add VAT at their country's rate. VAT registered subscribers should provide their VAT registration number. Orders, which must be accompanied by payment, may be sent to a bookseller, subscription agent or direct to the publisher: Cambridge University Press, Journals Fulfillment Department, UPH, Shaftesbury Road, Cambridge CB2 8BS, UK. Orders from the USA, Canada and Mexico should be sent to Cambridge University Press, 1 Liberty Plaza, Floor 20, New York, NY 10006, USA. Japanese prices for institutions are available from Kinokuniya Company Ltd, P.O. Box 55, Chitose, Tokyo 156, Japan. Prices include delivery by air.

Claims for missing issues should be made immediately on receipt of the subsequent issue.

Copying This journal is registered with the Copyright Clearance Center, 222 Rosewood Drive, Danvers, MA 01923. Organizations in the USA who are also registered with the C.C.C. may therefore copy material (beyond the limits permitted by sections 107 and 108 of US copyright law) subject to payment to C.C.C. of the per copy fee of $\$ 12.00$. This consent does not extend to multiple copying for promotional or commercial purposes. Code 0261$1430 / 2013 \$ 12.00$. Organizations authorized by the Copyright Licensing Agency may also copy material subject to the usual conditions.

ISI Tear Sheet Service, 3501 Market Street, Philadelphia, Pennsylvania 19104, USA, is authorized to supply single copies of separate articles for private use only.

For all other use, permission should be sought from the Cambridge or New York offices of Cambridge University Press.

INTERNET ACCESS This journal is included on Cambridge Core at cambridge.org/core. For further information on Popular Music and all other Cambridge journals see http:/ / www.cambridge.org.

Front cover: Acoustic Guitar and the Old Tree. Music Theme with Acoustic Guitar.

(C) Shutterstock 2019 / www.shutterstock.com 
VOL. 38 NO. 2

May

Issue Editors: MARTIN CLOONAN JOHN STREET

\section{Popular Music}

\section{Contents}

iii The Contributors

\section{Obituary}

SIMON FRITH 179 Dave Laing

\section{Articles}

CHRIS GIBSON

183 A sound track to ecological crisis: tracing guitars all the way back to the tree

CHRIS ATTON 204 Challenging authenticity: fakes and forgeries in rock music

ULRIK VOLGSTEN 219 A technology and its vicissitudes: playing the gramophone in Sweden 1903-1945

ROSEMARY LUCY HILL AND HEATHER SAVIGNY

MATT BRENNAN JO COLLINSON SCOTT ANGELA CONNELLY AND GEMMA LAWRENCE

KIERAN JAMES AND REX WALSH

ODED EREZ AND NADEEM KARKABI

RACHEL E. LOVE
237 music

252 Do music festival communities address environmental sustainability and how? A Scottish case study

276 Religion and heavy metal music in Indonesia

298 Sounding Arabic: postvernacular modes of performing the Arabic language in popular music by Israeli Jews

317 Talking Italian blues: Roberto Leydi, Giovanna Marini and American Influence in the Italian folk revival, 1954-66 


\section{Middle Eight}

MARCO BIASIOLI 335 Crosstown Traffic Conference - a review

\section{Reviews}

SIMON FRITH 341 Power to The People: British Music Videos 19662016

BILL BRUFORD 344 Music as Creative Practice, by Nicholas Cook

ALF BJÖRNBERG 346 Postwar Europe and the Eurovision Song Contest, by Dean Vuletic

SARAH BISHOP 348 Listening for Africa: Freedom, Modernity, and the Logic of Black Music's African Origins, by David F. Garcia

ALEXIS BENNETT 350 Time in the Blues, by Julia Simon

JEREMY MAYALL 352 Over and Over: Exploring Repetition in Popular Music, by Oliver Julien and Christophe Levaux

KEVIN HIGGINS 354 Black and Blur, by Fred Moten

\section{Erratum}

PEDRO SILVA MARRA 360 Sound, music, and magic in football stadiums AND FELIPE TROTTA 


\section{The Contributors}

Chris Atton is Professor of Media and Culture in the School of Arts and Creative Industries at Edinburgh Napier University. His books include Alternative Media, Alternative Journalism and the Routledge Companion to Alternative and Community Media. He has made special studies of fanzines and the media of new social movements, as well as the cultural value of avant-garde and other 'difficult' forms of popular music.

Matt Brennan is Reader in Popular Music and Convenor of the M.Litt Music Industries degree at the University of Glasgow. He has served as Chair of the UK-I branch of the International Association for the Study of Popular Music. His first monograph, When Genres Collide, was named one of Pitchfork's 'Favourite Music Books of 2017'.

Jo Collinson ScotT is a Lecturer in Commercial Music at the University of the West of Scotland where she helped to develop the MA Music: Songwriting degree. Her practice-led research work (carried out under her performing name 'Jo Mango') focuses on songwriting and social change in fields such as criminal justice, environmental sustainability and mental health.

Angela Connelly is a Lecturer in Architecture and a Research Associate in Planning and Environmental Management at the University of Manchester. Her research currently focuses on creative and collaborative approaches to enabling climate change adaptation in practice.

Oded ERez is a lecturer in the Department of Music at Bar Ilan University. His research focuses on the intersection of aesthetics and politics in Mediterranean popular music and cinema. His chapter on popular music will appear in the Routledge Handbook on Contemporary Israel (forthcoming 2020). He is currently completing a book manuscript on Greek music and ethno-class politics in Israel, as well as articles on music education in Arab-Israeli schools and on Israeli-Moroccan 'reverse diasporas'.

Chris GiBSON is Professor of Human Geography at the University of Wollongong, Australia. His research interests span geography, music, cultural economy, and more recently, material cultures of making and resource use. His books include Sound Tracks: Popular Music, Identity and Place (Routledge 2003) and Music Festivals and Regional Development (Routledge, 2012), co-written with John Connell, and Surfing Places, Surfboard Makers (University of Hawai'i Press, 2013), co-written with Andrew Warren. His forthcoming book with Andrew, Enchanted Wood, follows guitars from factory to forest.

Rosemary Lucy Hitl is a Senior Lecturer in Media Studies in the School of Music, Humanities and Media at University of Huddersfield. She is the author of Gender, 
Metal and the Media: Women Fans and the Gendered Experience of Music (Palgrave) and numerous articles on the politics of data visualisations. She researches gender, popular music and big data and is currently investigating sexual violence at live music events.

KIERAN JAMES is a Senior Lecturer in the School of Business and Enterprise at University of the West of Scotland. He was formerly Accounting Professor at University of Fiji. He researches in industrial relations, Marxism, popular music and sports history. He has published articles in International Journal of Sport Management $\mathcal{E}$ Marketing, Musicology Australia, Punk $\mathcal{E}$ Post-Punk and Sporting Traditions.

NADEEM KARKABI is a lecturer at the Department of Anthropology at the University of Haifa. His current research focuses on aspects of ethnicity, religion, language and nationalism in Jewish-Arab intersections in Israeli popular music, as well as on cultural production and performance in the Palestinian alternative music scene and in the Golan Heights' borderland.

Gemma Lawrence is the Producer for Creative Carbon Scotland, a charity focused on harnessing the role of the cultural sector in addressing the climate crisis. Gemma leads on the organisation's culture/SHIFT programme which supports collaborations between cultural and sustainability sectors to apply different ways of thinking and working to address complex sustainability problems.

RACHel E. Love is a CORE Postdoctoral Teaching Fellow at New York University, having earned her PhD from NYU in Italian Studies in May 2018. Her essays on 20th-century Italian politics and culture have appeared in the journals Modern Italy and Interventions.

Heather Savigny is Professor of Gender, Media and Politics at the Leicester Media School, De Montfort University. She publishes widely in these areas and her work has appeared in Feminist Media Studies, Media, Culture $\mathcal{E}$ Society, Metal Music Studies, British Journal of Political Science and International Relations and Gender, Work and Organisation. She is currently working on a monograph: 'Feminism, Metal and Politics'.

ULRIK VOLGSTEN is professor of Musicology at Örebro University, Sweden. His research is concerned with musical communication in different media. In addition to the conceptual history of Western music (composer, work, listener) and musical aesthetics, an important focus of research has been on the role of affect attunement for the musical experience.

Rex WALSH has qualifications in business, law and education. He has been fortunate to work across many universities and he has also taught in most units within business and law. His research interests include ethics and contemporary issues in accounting, particularly social and environmental reporting. He is currently working for a community legal service and undertaking professional consultancy work. 